of shock, as determined from the dimensions of a body which it has overturned, is a quantity not obtainable from an earthquake diagram. It represents the effect of a sudden impulse. In an earthquake a body is overturned or shattered by an acceleration, $f$, which is calculable for a body of definite dimensions. As obtained from an earthquake diagram $f$ lies between $\frac{V}{t}$ and $\frac{V^{2}}{a}$, where $V$ is the maximum velocity, $t$ is the quarter period, and $a$ is the amplitude. The initial velocity given in the formula $V^{2}=\frac{2 a^{2}}{b}$ for horizontal projection used by Mallet as identical with $V^{2}$ in the first formula, are not identical quantities. The velocity calculated from the range of projection, when projection occurs, is identical with the maximum velocity as measured directly or calculated from a diagram. The values $\frac{V^{2}}{a}$ are those used by Prof. Milne in discussing the intensity of movement. The intensity of an earthquake at first decreases rapidly as the disturbance radiates, subsequently it decreases more slowly. A curve of intensities deduced from observations at a sufficient number of stations would furnish the means of approximately calculating an absolute value for the intensity of an earthquake.

Vertical Motion.-In soft ground vertical motion appears to be a free surface-wave which advances more rapidly than the borizontal component of motion. It commences with small, rapid vibrations, and ends with vibrations which are long and slow. High velocities of transit may be obtained by the observation of this component of motion, and this is possibly an explanation of the preliminary tremors of an earthquake and the sound phenomenon.

Velocity. - The velocity 'of transit decreases as a disturbance radiates; near to an origin it varies with the intensity of the initial disturbance. In different kinds of ground, with different intensities of initial disturbance, and with different systems of observation, velocities lying between 630 feet and 200 feet per second were determined. Mr. Mallet determined a velocity in sand of 824 feet, and in granite of $\mathbf{1} 664$ feet per second. Gen. Abbot observed velocities of 8800 feet. These various determinations may all be strictly correct, the great difference between them being due partly to the nature of the rock, the intensity of the initial disturbance, and the kind of wave which was observed. In Prof. Milne's experiments the vertical free surface wave had the quickest rate of transit, the normal being next, and the transverse motion being the slowest; but the rate at which the normal motion exceeds the transverse is not constant. As the amplitude and period of the normal motion approach in value those of the transverse motion, so do the velocities of transit of these motions approach each other.

In stating the results, of which those given above are the principal, Prof. Milne refers to the particular experiments which support them, thus giving chapter and verse for his conclusions; but he thinks that if the investigations were repeated by himself or by any other investigator, although much of what he has recorded would be substantiated, more accurate results might be obtained by taking advantage of his experience. Finally he gives examples of investigations which have yet to be undertaken, and as these are valuable for others working in the same field, we append them here:-(I) An accurate determination of the rate at which the velocity of transit decreases as a disturbance radiates from its origin; (2) the relation between the velocity of transit and the intensity of the initial disturbance ; (3) the determination of the rate at which the intensity of a disturbance decreases as measured at different distances from the origin. This might perhaps lead to the construction of a curve of intensities from which the absolute intensity of the initial disturbance could be learnt ; (4) a more complete investigation of the vertical motion and of free surface waves; (5) an investigation of the inward motion of shocks. In Prof. Milne's experiments the movement of the ground from its neutral position in towards the origin of the disturbance has been performed so rapidly that he has been unable with the instruments at his disposal to measure its velocity accurately. As this is probably the most destructive element of motion, he regards its investigation as exceedingly important ; $(6)$ further investigations on the relationship between earthquake diagrams, and the overturning and projecting of various bodies ; (7) a repetition of these and of all other experiments, on different kinds of ground.

\section{THE INFLUENCE OF FORESTS ON CLIMATE}

THE third number of Petermann's Mittheilungen for this year contains an article by Herr $\mathrm{A}$. Woeikof on the influence of forests on climate. The commencement of a scientific investigation of this subject was made when the Bavarian forest meteorological stations were established, and when Prussia, Alsace-Lorraine, France, Switzerland, and Italy followed the example. As a general rule it may be laid down that in the warm seasons, as between forests and places close at hand which are treeless (I) the temperatures of the earth and air are lower in the former, (2) their variations are less, (3) the relative humidity is greater. After examining observations as to evapora. tions, Herr Woeik of states that the influence of forests in diminishing evaporation from water and the soil is so great that it cannot be accounted for alone by the lower temperature of the hot months, the greater humidity, or even by the shade. An important influence, which has hitherto been but little appreciated, is the protection from the wind afforded by the trees, and this the writer regards as more important than all the others together in reducing the degree of evaporation. With regard to the influence of forests on rain and snowfall, there is as yet only a single series of observations supplying comparative statistics, and extending over a sufficiently long period. These were taken in the neighbourhood of Nancy, and they show an important influence of forests in increasing the rainfall. It might appear that the effect of forests on rain in the climate of Central Europe in winter would be small, for the difference between the temperature and humidity of the forest and the open is very little, and the quantity of moisture in the atmosphere is small. But the observations show that it is at this time of the year that forests get much more rain. This the writer attributes to the clouds being lower, the resistance which the forest offers to the movement of the air, and to the moist west wind. Forests retain rain by the undergrowths of grass, moss, \&c., much better than open ground, and let water off superficially only after a heavy rainfall; the remainder filters upwards slowly, and much of it is used for the evaporation of the trees. Although forests, especially thick, luxuriant forests, cannot exist without certain supplies of moisture, yet it is the same to them when the supplies come, for they retain what they get and use it over a long period. One example of this is the Lenkoran forest on the west coast of the Caspian, where the vegetation is more luxuriant than in any other part of Europe, yet very little rain falls in summer, but the rainfall in autumn and winter is great. The water is stored up by the forest, and is used in evaporation during the heat of summer. Humidity of the atmosphere, however, is not inconsistent with a high temperature, as the Red Sea shows; but in forests the humidity is due to the evaporation of the leaves-in other words, to a process by which heat is converted into work, and hence the coolness. Herr Woeik of then endeavours to ascertain the influence of forests on the climatic conditions of their neighbourhoods in the western parts of the. Old World, between the 38 th and 52nd degrees N. latitude, the places selected being in all cases in the open. Thus for the 52nd degree eight stations are taken between Valentia in Ireland on the west and the Kirghiz steppes on the east; for the 5oth, Guernsey on the west, Semipalatinsk on the east, and thirteen stations, and so on for each two degrees of latitude to $38^{\circ}$. The general result of the observations in fifty-stations in six different degrees of latitude is that in Western Europe and Asia large forests have a great influence on the temperature of places near them, and that by their influence the normal increase of temperature as we travel eastward from the Atlantic Ocean to the interior of the continent is not merely interrupted, but they give places far removed from the coast a cooler summer than those actually on the sea. A striking example of this is Bosnia. An examination of the statistics shows (I) that in Bosnia the summer is $2^{\circ} \cdot 5$ to $4^{\circ} \cdot 5$ cooler than in Herzegovina ; (2) even on the island of Lissa, in the full influence of the Adriatic Sea, the summer temperature is more than a degree higher than that of Bosnia, which is separated by lofty mountain ranges from the sea. Bosnia owes this comparatively cool summer to its great forests, while Herzegovina is almost disafforested. To sum up: forests exercise an influence on climate which does not cease on their borders, but extends over a larger or smaller adjacent region according to the size, kind, and position of forest. Hence man by afforestation and disafforestation can modify the climate around him; but it is an extreme position to hold that by afforestation the waste places 
of the earth can be made fertile. There are places incapable of being afforested, which would not give the necessary nourishment to trees.

\section{ORIGIN OF THE CEREALS}

$\mathrm{R}$ ECENT numbers of Naturen contain interesting papers, by $\mathrm{R}$ Prof. Schibeler, on the original habitat of some of the cereals, and the subsequent cultivation in the Scandinavian lands and Iceland of barley and rye more especially. It would appear that barley was cultivated before other cereals in Scandinavia, and that the generic term "corn" was applied among Northmen to this grain only from the oldest times, and that in the Nor. wegian laws of the seventeenth and eighteenth centuries wherever reference was made to the "Kornskat" - or standard by which land in the Northern lands was, and still is, rated in accordance with the corn it is capable of yielding-the term was understood to apply to barley. Proof of the high latitude to which the cultivation was carried in early ages is afforded by the Egil's Saga, where mention is made of a barn in Helgeland $\left(65^{\circ} \mathrm{N}\right.$. lat.) used for the storing of corn, and which was so large that tables could be spread within it for the entertainment of 800 guests. In Iceland barley was cultivated from the time of its colonisation, in 870 , till the middle of the fourteenth century, or, according to Jón Storrason, as lately as 1400. From that period down to our own times barley has not been grown in Iceland with any systematic attention, the islanders being dependent on the home country for their supplies of corn. In the last century, however, various attempts were made both by the Danish Government and private individuals to obtain homegrown corn in Iceland, and the success with which these endeavours were attended gives additional importance to the systematic undertaking, which has been set on foot by Dr. Schuibeler and others, within the last three years, for the introduction into the island of the hardier cereals, vegetables, and fruits. As many as 382 samples of seeds of ornamental and useful plants, most of which were collected from the neighbourhood of Christiania, are now being cultivated at Reykjavik under the special direction of the local government doctor, Herr Schierbeck, who succeeded in 1883 in cutting barley ninety-eight days after the sowing of the seed, which had come from Alten $\left(70^{\circ} \mathrm{N}\right.$. lat.). And here it may be observed that this seems the polar limit in Norway for anything like good barley crops. The seed is generally sown at the end of May, and in favourable seasons it may be cut at the end of August; the growth of the stalk being often $2 \frac{1}{2}$ inches in twenty-four hours. North of $60^{\circ}$ or $6 \mathbf{I}^{\circ}$ barley cannot be successfully grown in Norway at more than from I800 to 2000 feet above the sea-level. In Sweden the polar limit is about $68^{\circ}$ or $66^{\circ}$, but even there, as in Finland, night-frosts prove very destructive to the young barley. In some of the fjeld valleys of Norway, on the other hand, barley may in favourable seasons be cut eight or nine weeks after its sowing, and thus two crops may be reaped in one summer. According even to a tradition current in Thelemarken, a farm there owes its name Triset to the three crops reaped in the land in one year! Rye early came into use as a hread-stuff in Scandinavia, and in 1490 the Norwegian Council of State issued an ordinance making it obligatory on every peasant to lay down a certain proportion of his land in rye. In Norway the polar limit of summer rye is about $69^{\circ}$, and that of winter rye about $61^{\circ}$; but in Sweden it has been carried along the coast as far north as $55^{\circ}$. The summer rye crops are generally sown and fit for cutting about the same time as barley, although occasionally in Southern Norway less than ninety days are required for their full maturity.

\section{UNIVERSITY AND EDUCATIONAL INTELLIGENCE}

The Gilchrist Trustees have instituted a Scholarship of the annual value of $50 \%$, for three years, tenable at either Girton or Newnham College, Cambridge, to be awarded in connection with the Cambridge Higher Local Examination. 'The first award will be made on the results of the examination to be held in June. Further information may be obtained from the secretaries of the two colleges.

AT a recent meeting of the Senate of the Royal University of Ireland, two Fellows in the Department of Natural Science were elected. The successful competitors were the Rev. Marshal
L. Klein, of the Catholic University College, and Mr. Marcus M. Hartog, Professor of Natural History, Queen's College, Cork. The salary attached to each of the Fellowships is $400 l$. a year.

\section{SCIENTIFIC SERIALS}

The Qurterly Fournal of Microscopical Science, April, contains :-On the urinary organs of the Amphipoda, by W. B. Spencer, B.A. (plate 13). - The skin and nervous system of Priapulus and Halicryptus, by R. Scharff, Ph.D. (plate 14).The eye and optic tract of insects, by S. J. Hickson, B.A. (plates I 5-1 7). - A peculiar sense organ in Scutigera coleoptrata, one of the Myriopoda, by F. G. Heathcote, B.A. (plate 18). The structure and development of Loxosoma, by S. F. Harmer B. Sc. (plates I9-2I). - A new hypothesis as to the relationship of the lung-book of Scorpio to the gill-book of Limulus, by $\mathrm{E}$. R. Lankester, M.A.-A supplement number is announced to be published during May.

The Fournal of the Royal Microscopieal Society for April contains :-The Rev. W. H. Dallinger's address as President (plates 4-6). - The Lantern Microscope, by L. Wright. - On some unusual forms of lactic ferment; Bacterium lactis, by R. L. Maddox, M. D.-On a cata-dioptric immersion illuminator, by J. W. Stephenson. - With the usual summary of current researches in zoology and botany.

American Fournal of Science, May.-Experiments undertaken to determine the modulus of elasticity of ice and the velocity of sound in ice, by John Trowbridge and Austin L. McRae. The average of all the observations was found to be $72 \times 10^{9}$ as compared with Bevan's absolute modulus $54 \times 10^{9}$. The velocity was determined at $2900 \mathrm{~m}$. per second, or about nine times the velocity of sound in air.-Contributions from the Agricultural Experiment Station of the University of Wisconsin : digestion experiments, by H. P. Armsby. These experiments, made on sheep fed with hay, clover, malt-sprouts, and cotton seed-meal, yielded so many uncertain results that no satisfactory averages could be determined. Such averages may be made the basis of the calculation of rations in practice; but neither they nor the single results upon any given fodder can properly enter into any scientific calculation of the nutritive effect of a ration.-Chemical analysis of massive safflorite, by Le Roy W. McCay.-Application of photography to the study of electrical measurements (two illustrations), by John Trowbridge and Hammond Vinton Hayes. On the production of alternating currents by means of a directcurrent dynamo-electric machine, by John Trowbridge and Hammond Vinton Hayes. - Chemical analysis of a variety of topaz discovered in $\mathbf{I} 882$ by Mr. N. H. Perry in the Stoneham district, State of Maine (two illustrations), by F. W. Clarke and J. S. Diller. - A notice of the relation observed by Dr. Weber between the residual elasticity and the chemical constitution of glass, by O. T. Sherman.-On the meridional deflection of ice-streams, as shown in the morains s of the extinct glaciers in the Mono Lake Valley, Eastern California (two illustrations), by W. J. McGee.-The pre-Glacial channel of Eagle River, Keweenaw Point, Lake Superior (one illustration), by Charles Whittlesey.-Note on the age of the slaty and arenaceous rocks in the vicinity of Schenectady, Schenectady County, New York, by S. W. Ford. These formations, usually referred to the epoch of the Lorraine shales, are regarded by the author as belonging to the Utica age. From them were obtained various fossils, including a species of Lingula which he considers to be the Utica species, L. curta.

The American Naturalist, March, contains :-Indian corn and the Indians, by E. L. Sturtevant.-The evolution of the Vertebrata, progressive and retrogressive, by E. D. Cope.-On the larval forms of Spirorbis borealis, by J. W. Fewkes. - Pennsylvania, before and after the elevation of the Appalachian Mountains ; a study in dynamical geology, by E. W. Claypole.-Life and nature in Southern Labrador, by A. S. Packard.

April. - Why certain kinds of timber prevail in certain localities, by J. T. Campbell.-The evolution of the Vertebrata, by E. D. Cope--Progress of North American Invertebrate palæontology for 1884 , by J. B. Marcou. - The clam-worm, by S. Lockwood. - Life and nature in Southern Labrador, by A. S. Packard.

May.-Some new Infusoria (with illustrations), by A. C. Stokes. - Kitchen-garden esculents of American origin (I.), by E. L. Sturtevant.-The Lemuroifea and the Insectivora of the 